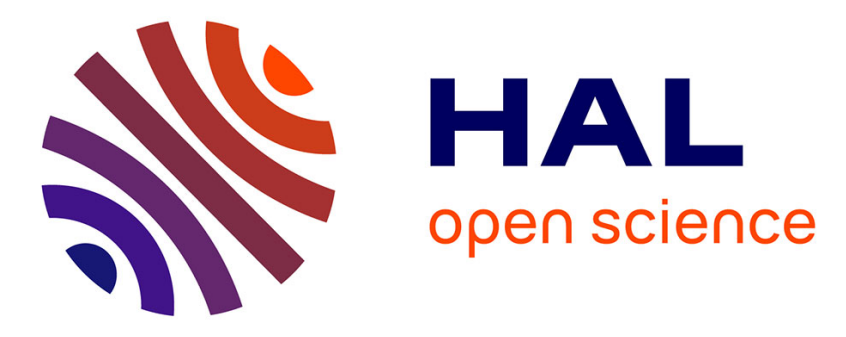

\title{
Combined process for 2,4-Dichlorophenoxyacetic acid treatment-Coupling of an electrochemical system with a biological treatment
}

Jean-Marie Fontmorin, Florence Fourcade, Florence Geneste, Didier Floner, Samuel Huguet, Abdeltif Amrane

\section{To cite this version:}

Jean-Marie Fontmorin, Florence Fourcade, Florence Geneste, Didier Floner, Samuel Huguet, et al.. Combined process for 2,4-Dichlorophenoxyacetic acid treatment-Coupling of an electrochemical system with a biological treatment. Biochemical Engineering Journal, 2013, 70, pp.17-22. 10.1016/j.bej.2012.09.015 . hal-00805125

\section{HAL Id: hal-00805125 \\ https://hal.science/hal-00805125}

Submitted on 6 Dec 2013

HAL is a multi-disciplinary open access archive for the deposit and dissemination of scientific research documents, whether they are published or not. The documents may come from teaching and research institutions in France or abroad, or from public or private research centers.
L'archive ouverte pluridisciplinaire HAL, est destinée au dépôt et à la diffusion de documents scientifiques de niveau recherche, publiés ou non, émanant des établissements d'enseignement et de recherche français ou étrangers, des laboratoires publics ou privés. 
Combined process for 2,4-Dichlorophenoxyacetic acid treatment - Coupling of an electrochemical system with a biological treatment.

$\underline{\text { Jean-Marie Fontmorin }}^{\mathrm{a}, \mathrm{b} *}$, Florence Fourcade ${ }^{\mathrm{a}, \mathrm{b}}$ Florence Geneste $^{\mathrm{c}, \mathrm{b}}$, Didier Floner $^{\mathrm{c}, \mathrm{b}}$, Samuel

$$
\text { Huguet }^{\mathrm{a}, \mathrm{b}} \text {, Abdeltif Amrane }{ }^{\mathrm{a}, \mathrm{b}}
$$

${ }^{a}$ Ecole Nationale Supérieure de Chimie de Rennes, CNRS, UMR6226, Avenue du Général Leclerc, CS 50837, 35708 Rennes Cedex7, France.

${ }^{b}$ Université Européenne de Bretagne

c Université de Rennes 1, CNRS, UMR 6226, Equipe Matière Condensée et Systèmes Electroactifs, Campus de Beaulieu, 35042 Rennes Cedex, France

\section{*Corresponding author}

Phone: +33 2232380 83; Fax: +332232381 20;

E-mail: jean-marie.fontmorin@ensc-rennes.fr

\section{Abstract}

A coupled process was studied for the removal of a chlorinated pesticide: 2,4Dichlorophenoxyacetic acid (2,4-D). A home-made electrochemical flow cell was used for the pre-treatment and a biological treatment was then carried out using activated sludge supplied by a local wastewater treatment plant. 2,4-D was used as a target compound for the study. Several parameters were monitored during the biological treatment, like Dissolved Organic Carbon (DOC), the target compound and the major by-product. Pretreatment led to a quick decrease of DOC during the biological process, since a $66 \%$ mineralization yield was measured after the second day, and $79 \%$ after the seventh day of culture. After two days of treatment, HPLC results revealed a total degradation of Chlorohydroquinone, the major by-product. The electrochemical pretreatment 
shortened the length of the biological treatment, since DOC measurements showed that in the case of non-pretreated 2,4-D, no mineralization was observed before day 7 . These promising results should be subsequently confirmed on commercial 2,4-D-containing solutions and then on real effluents.

Keywords: 2,4-D, carbon felt electrode, electrochemical pre-treatment, biodegradability, activated sludge, biological treatment

\section{Introduction}

The usage of pesticides in intensive agricultural practice has brought out environmental and health concerns since it negatively impacts water and soil quality. Removing pesticides to protect water resources has thus become a great challenge in current research [1]. Wastewater from agricultural industries like pesticides formulating plants or bottom farm tanks can contain high levels of pesticides (up to $500 \mathrm{mg} \mathrm{L}^{-1}$ ) [2]. Theses effluents need therefore to be treated by specific physical, chemical or biological processes.

2,4-Dichlorophenoxyacetic acid (2,4-D, Figure 1) is one of the most used phenoxyalkanoic herbicides in the world $[3,4]$, and more than 1500 pesticides contain 2,4-D as the main active substance [5]. Phenoxyalkanoic herbicides are considered as serious contaminants of streams, lakes and rivers [6], especially because of their high solubility in water and low tendency to accumulate in organic matter [7]. As a matter of fact, 2,4-D has frequently been detected in surface and ground waters in Europe and North America [8,9]. Moreover, 2,4-D is known to present serious ecological impact, like toxic effects on birds, beneficial insects, non-target plants but also on algae, small invertebrates, amphibians, fishes and more generally on aquatic life $[10,11]$. 
Over the past few decades, the literature has disclosed a plethora of studies focusing on 2,4-D degradation. Many bacterial strains capable of degrading 2,4-D have been isolated, such as several strains of Pseudomonas, Arthrobacter and Alcaligenes [12-16]. However, in many cases, the mineralization yield was low or even not measured [17]. The feasibility of a biological treatment based on pure strains of bacteria remains therefore limited, and 2,4-D removal was thus also studied with consortium of bacteria, isolated from soil samples or activated sludge from wastewater treatment plant. A $250 \mathrm{mg} \mathrm{L}^{-1} 2,4-\mathrm{D}$ concentration as a sole carbon source was degraded in 8 days using different enrichment cultures based on soil samples from a fertilizer manufacturing plant site [18]. Activated sludge from municipal wastewater treatment plant has also shown the ability to partially degrade a waste stream containing $10 \mathrm{mg} \mathrm{L}^{-1}$ of the herbicide [19]. Experiments carried out in Sequencing Batch Reactors (SBRs) led to the removal of a $100 \mathrm{mg} \mathrm{L}^{-1}$ 2,4-D concentration. However, a 4 months acclimation period of the activated sludge was necessary [8]. More recently, this acclimation period was reduced to 30 days to degrade up to $500 \mathrm{mg} \mathrm{L}^{-1}$ of 2,4-D, but this results were obtained with a biomass that was previously exposed to the pesticide [20]. Despite the economical advantage of the activated sludge, the efficiency of the biological treatment can be limited with recalcitrant compound and also be time-consuming when a long acclimation period is necessary.

2,4-D removal has been thoroughly studied using ozonation processes [21-23] or Advanced Oxidation Processes (AOPs) like anodic oxidation, Fenton and Fenton-like processes [24-27], photocatalysis $[28,29]$. Despite their efficiency, the total mineralization of the effluent to treat can be time and energy-consuming, thus increasing operational costs. Moreover, these processes showed other drawbacks such as the disposal of iron waste in case of Fenton and Fenton-like processes. The combination of AOP with biological treatments can therefore 
appear as a good alternative to reduce operating costs. The aim of the pre-treatment step is to increase the biodegradability of the initial biorecalcitrant solution; the intermediates formed should therefore be more biodegradable than the target compound, while the mineralization yield should remain limited to ensure significant residual organic carbon content for the subsequent biological treatment and to limit the energy costs. The literature reports numerous studies dealing with AOPs as pre-treatment steps prior to biological processes. For example, isoproturon was mineralized by combining heterogeneous photocatalysis with a bioreactor containing bacteria supported on biolite [30]. The herbicides diurion and linuron treated by photo-Fenton led to non-toxic and biodegradable intermediates that were degraded in a biological Sequencing Batch Reactor [31].

As an alternative to Advanced Oxidative Processes, electrochemical systems can also be considered. Electrochemical systems were already combined with biological processes to remove heavy metals or nitrates from different wastewaters [32,33]. Regarding organic recalcitrant compounds, the biodegradability of a $100 \mathrm{mg} \mathrm{L}^{-1}$ tetracycline solution was found to increase after electrolysis in a home-made flow cell involving a carbon felt electrode [34], as well as the biodegradability of a $1000 \mathrm{mg} \mathrm{L}^{-1}$ acetamipirid solution after pretreatment using a boron-doped diamond electrode [35]. In both cases, the Biological Oxygen Demand after 5 days $\left(\mathrm{BOD}_{5}\right)$ on Chemical Oxygen Demand $(\mathrm{COD})$ ratio $\left(\mathrm{BOD}_{5} / \mathrm{COD}\right)$ increased from negligible values for the target compounds to above 0.4 , namely the limit of biodegradability, after the electrochemical pretreatment, showing that the produced intermediates can be most likely biodegraded during biological treatment. However and to our knowledge, the implementation of an electrochemical pretreatment and a biological process seems to be only performed for the treatment of an herbicide, phosmet, leading to $97 \%$ of mineralization [36]. 
The feasibility of the electrochemical pre-treatment to increase the biodegradability of 2,4-D was previously shown in the laboratory [37]. The electrochemical step was based on a homemade flow cell using bare graphite felt as a working electrode. The graphite felt presents several advantages, like its moderate cost and its high specific area. The electrochemical behavior of the target compound was investigated and major intermediates were detected and quantified. To complete this previous work, the relevance of the combined process for 2,4-D treatment should be assessed. This task was the main purpose of this work. The aerobic biological treatment was carried out using activated sludge purchased from a local wastewater treatment plant. Assessment of the efficiency of the combined process was based on the monitoring of specific parameters namely the target compound and the major by-products (HPLC measurements) on the one hand, and global parameters namely mineralization and oxidation through the determination of DOC and COD values on the other hand.

\section{Experimental}

\subsection{Chemicals}

2,4-Dichlorophenoxyacetic acid (98\%) was purchased from Alfa Aesar (Schiltigheim, France). Acetonitrile (ACN) and formic acid were LC/MS grade from JT Baker (Deventer, Netherlands). All standards were prepared with ultra pure water (PurelabOptions-Q7/15, Elga, 18.2 M $\Omega . c m)$.

\subsection{Materials for the electrochemical pre-treatment}

The electrochemical pre-treatment has been carried out as previously described [37]. This electrochemical step was based on a home-made flow cell using a graphite felt as a working electrode supplied by Mersen (RVG 4000 - Mersen, Paris La Défense, France). The dimensions of the graphite felt were $48 \mathrm{~mm}$ diameter and $12 \mathrm{~mm}$ width. 
A potential of $1.6 \mathrm{~V} / \mathrm{SCE}$ was applied using a VersaSTAT 3 potentiostat from Ametek/Princeton Applied (Elancourt, France). The cell was thoroughly rinsed with distilled water before and after each experiment. The electrolyte solution $\left(500 \mathrm{mg} \mathrm{L}^{-1} 2\right.$,4-D in $0.1 \mathrm{M}$ $\mathrm{Na}_{2} \mathrm{SO}_{4}$ ) percolated the porous electrode at a constant flow rate of $1 \mathrm{~mL} \mathrm{~min}{ }^{-1}$ monitored by a Gilson minipuls 2 peristaltic pump (Middleton, WI, USA).

\subsection{Biological treatment}

After only one pass through the electrochemical flow-cell, the effluent was collected for the subsequent biological treatment, which was carried out in aerobic conditions, using activated sludge purchased from the local wastewater treatment plant (Station de Beaurade, Rennes, France). Before use, activated sludge was washed four times with tap water and once with distilled water. After each washing, activated sludge was centrifuged at $3000 \mathrm{rpm}$ for five minutes (Jouan, Thermo Fisher Scientifics, Saint Herblain, France). The supernatant was then separated from the sludge to remove any residual carbon or mineral source.

Experiments were carried out in $250 \mathrm{~mL}$ erlenmeyer flasks containing $100 \mathrm{~mL}$ of medium, stirred at $250 \mathrm{rpm}$, kept at $30^{\circ} \mathrm{C}$ and triplicated to ensure the reproducibility of the results. The following mineral basis was added to each experiment (mg L ${ }^{-1}$ ): $\mathrm{KH}_{2} \mathrm{PO}_{4}: 85, \mathrm{~K}_{2} \mathrm{HPO}_{4}$ : 208 , $\mathrm{Na}_{2} \mathrm{HPO}_{4} .2 \mathrm{H}_{2} \mathrm{O}: 334, \mathrm{CaCl}_{2}: 27.6, \mathrm{MgSO}_{4} \cdot 7 \mathrm{H}_{2} \mathrm{O}: 22.6, \mathrm{FeCl}_{3} \cdot 6 \mathrm{H}_{2} \mathrm{O}: 0.26, \mathrm{NH}_{4} \mathrm{Cl}: 75$. Erlenmeyer flasks were inoculated with $0.5 \mathrm{~g} \mathrm{~L}^{-1}$ of activated sludge. The initial target compound, 2,4-D, concentration was $100 \mathrm{mg} \mathrm{L}^{-1}$ and the electrolyzed solution (initially 500 $\mathrm{mg} \mathrm{L}^{-1} 2,4-\mathrm{D}$ ) was diluted (five times dilution) to allow a direct comparison to non-treated 2,4-D. The sole carbon source for microorganisms was therefore $2,4-\mathrm{D}$ on the one hand or the electrolyzed solution on the other hand. A biological treatment carried out in similar conditions but lacking of any carbon source was used as a "blank" test. The $\mathrm{pH}$ of each assay was then adjusted to $7.0 \pm 0.2$ using $1 \mathrm{~mol} \mathrm{~L}^{-1} \mathrm{NaOH}$. 
Samples $(5 \mathrm{~mL})$ were taken every 2 or 3 days and filtered on $0.45 \mu \mathrm{m} . \mathrm{pH}$ measurements were carried out using a pHmeter Hanna with a combined micro-electrode probe (Thermo Spectronic, Rochester, USA). Samples were then diluted for DOC, COD and HPLC measurements.

\subsection{Analysis}

\subsubsection{HPLC}

Measurement of the residual 2,4-D and Chlorohydroquinone concentration were performed by HPLC (High Pressure Liquid Chromatography) (Milford, USA) system involving a pump Waters 600, fitted with a Phenomenex Kinetex® C18 2.6 ${ }^{\circledR}$ m column (4.6 mm x 100 mm), along with a Waters 996 Photodiode array detector, a Waters 717 ph Autosampler and controlled through an Empower® 2 program. The mobile phase consisted of acetonitrile and trifluoroacetic acid (TFA) $0.1 \%$ in ultra-pure water with a ratio of $30 / 70$ at $1 \mathrm{ml} . \mathrm{min}^{-1}$.

\subsubsection{Dissolved Organic Carbon (DOC) measurements}

After electrolysis, the solutions were filtered on a Satorius Stedim Minisart $0.40 \mu \mathrm{m}$ GF prefilters (Goettingen, Germany). DOC was measured by means of a TOC-V $\mathrm{V}_{\mathrm{CPH} / \mathrm{CPN}}$ Total Organic Analyzer Schimadzu. Organic carbon compounds were combusted and converted to $\mathrm{CO}_{2}$, which was detected and measured by a non-dispersive infrared detector (NDIR). Reproducible DOC values were always obtained using the standard NPOC (Non Purgeable Organic Carbon) method. For DOC, COD and $\mathrm{BOD}_{5}$ measurements, a 2,4-D solution (100 mg $\mathrm{L}^{-1}, \mathrm{Na}_{2} \mathrm{SO}_{4} 0.02 \mathrm{M}$ ) was considered as the reference. The electrolyzed solution (initially 2,4D $500 \mathrm{mg} \mathrm{L}^{-1} \mathrm{Na}_{2} \mathrm{SO}_{4} 0.1 \mathrm{M}$ ) was always diluted by 5 so the results obtained can be directly compared to the reference.

\subsubsection{Chemical Oxygen Demand (COD) measurements}

Chemical Oxygen Demand (COD) was measured by means of a Test Nanocolor® CSB 160 from Macherey-Nagel (Düren, Germany). The amount of oxygen required for the oxidation of 
the organic and mineral matter at $164^{\circ} \mathrm{C}$ for 30 min was quantified after oxidation with $\mathrm{K}_{2} \mathrm{Cr}_{2} \mathrm{O}_{7}$ at acidic $\mathrm{pH}$ and heating.

\section{Results and discussion}

\subsection{Electrolysis on carbon felt electrode}

The electrochemical behavior and electrolysis of 2,4-D were investigated in a previous study, and promising results were obtained, showing the improvement of the biodegradability of the target compound [37]. As explained in this previous study, electrolysis was carried out in oxidation at $1.6 \mathrm{~V} / \mathrm{SCE}$, at a flow rate of $1 \mathrm{~mL} \min ^{-1}$. After a single pass through the electrochemical flow cell, the effluent was collected for analysis, and was first analyzed by cyclic voltammetry (Fig. 2). The initial oxidation signal of 2,4-D decreased and a quasireversible signal appeared at about $0.3 \mathrm{~V} / \mathrm{SCE}$. The 2,4-D degradation was confirmed by HPLC since high removal and mineralization (deduced from DOC measurements) yields were obtained, $96 \pm 3 \%$ and $34 \pm 4 \%[37]$.

In order to assess the feasibility of the biological treatment, the biodegradability of both the 2,4-D and the electrolyzed 2,4-D solution were determined, considering that an effluent can be considered as easily biodegradable if its $\mathrm{BOD}_{5} / \mathrm{COD}$ ratio exceeds $0.4[38,39]$. As presented in table 1 , this ratio increased from 0.04 before electrolysis to 0.25 after electrolysis, showing a significant increase of the effluent's biodegradability; hence and even if the limit of biodegradability was not achieved a biological treatment could be promisingly considered. Finally, the major degradation by-products were identified by LC/MS/MS and GC/MS, and quantified by HPLC. Chlorohydroquinone (Figure 1) was identified as the major by-product since it represented $35 \%$ of the residual organic carbon [37].

\subsection{Biological treatment}


Prior to the biological treatment step, possible biosorption on activated sludge of 2,4-D on the one hand and the major by-product, Chlorohydroquinone, for the electrolyzed effluent on the other hand was assessed. Results are depicted in Figure 4. $250 \mathrm{~mL}$ Erlenmeyer flasks containing $100 \mathrm{~mL}$ of medium were inoculated with $0.5 \mathrm{~g} \mathrm{~L}^{-1}$ of activated sludge, which was washed in the same conditions as the biological treatment. The flasks were stirred at $250 \mathrm{rpm}$ and the experiments were triplicated to ensure the reproducibility of the results. 2,4-D concentration in the untreated effluent on the one hand, and Chlorohydroquinone in the oxidized effluent on the other hand, were monitored by HPLC throughout biosorption experiments. Samples were regularly taken over a 3 hours period, filtered on $0.45 \mu \mathrm{m}$ and then analyzed by HPLC. As displayed in Figure 3, no significant decrease of 2,4-D or Chlorohydroquinone concentrations was detected after 3 hours, showing that neither2,4-D nor Chlorohydroquine were biosorbed on activated sludge. Indeed, as biosorption is a rapid phenomenon, it would have been noticed within the 3 hours of experiment.

The biological treatment was then run in aerobic conditions, and several parameters were monitored over a 21 days period. Samples were regularly taken to measure pH, DOC, 2,4-D and Chlorohydroquinone concentrations.

Evolution of DOC during the biological treatment is presented in Figure 4a. The initial DOC concentration was higher for the 2,4-D solution than for the electrolyzed solution, since the electrochemical step led to a $34 \%$ mineralization. No decrease of DOC was observed in 2,4-D samples until day 7 . This steady phase corresponded most likely to a lag phase or a short acclimation period of microorganisms to $2,4-\mathrm{D}$, since the pesticide was the sole available carbon source. A similar lag phase was already observed in other studies using soil samples instead of activated sludge [18]. A decrease of the DOC was then observed between day 7 and day 12. During this lapse of time, $87 \%$ of the organic carbon were mineralized, the DOC 
concentration measured in the blank test being considered as the reference $(100 \%$ mineralization). This decrease of DOC corresponded to a mineralization rate of $14.1 \mathrm{mg} \mathrm{L}^{-1}$ day $^{-1}$. From day 12 and until day 14, a low mineralization yield of $8 \%$ was observed; DOC values remained then constant until the end of culture. It should also be noted that the final concentration of dissolved organic carbon during non-pretreated 2,4-D experiments was as low as the concentration of dissolved organic carbon in the blank test $\left(15.9 \mathrm{mg} \mathrm{L}^{-1}\right.$ compared to $17.1 \mathrm{mg} \mathrm{L}^{-1}$ ). At a concentration of $100 \mathrm{mg} \mathrm{L}^{-1}, 2,4-\mathrm{D}$ and its intermediates were thus fully biodegraded after 21 days. The HPLC monitoring of the 2,4-D concentration confirmed DOC results, as displayed in Figure 4b. No significant 2,4-D degradation was observed until day 7, in agreement with the observation drawn from DOC measurements (Figure 4a), and hence the period of acclimation of activated sludge to the pesticide was confirmed. 2,4-D was then fully degraded in between day 7 and day 14 , at a removal rate of $13.7 \mathrm{mg} \mathrm{L}^{-1}$ day $^{-1}$. Since 2,4-D and DOC time-courses showed similar trends at nearly similar rates with a complete removal after 14 days in both cases, it can be assumed that the degradation products resulting from 2,4-D biodegradation were readily assimilable by microorganisms, leading to a total mineralization. Chemical Oxygen Demand was also measured at the end of the biological treatment. As presented in Table 1, the COD of 2,4-D samples decreased from $182 \mathrm{mg} \mathrm{O} \cdot \mathrm{L}^{-1}$ to $38 \mathrm{mg}$ $\mathrm{O}_{2} \cdot \mathrm{L}^{-1}$ (namely $79 \%$ decrease). This result was thus in agreement with the DOC and 2,4-D concentrations tendencies previously described.

In the case of the electrolyzed effluent, no significant lag phase was observed since a $39 \%$ decrease of the initial DOC was measured after only one day of culture. This observation illustrated a readily assimilation of some of the degradation products. Mineralization continued until day 5 of culture, since $77 \%$ mineralization yield was measured, corresponding to a mineralization rate of $10 \mathrm{mg} \mathrm{L}^{-1}$ day $^{-1}$. After day 5 , no really significant decrease of the initial dissolved organic carbon was measured until day 21 since only $8 \%$ of the DOC were 
mineralized during this period, corresponding to a mineralization rate of $0.3 \mathrm{mg} \mathrm{L}^{-1}$ per day. Residual 2,4-D concentration was also monitored in the oxidized effluent (Figure 4b). 2,4-D concentration was stable until day 12 and fully degraded at day 14, probably corresponding to the acclimation of the microorganisms. However, no decrease of the Dissolved Organic Carbon was measured between day 14 and day 21, and this concentration remains slightly higher than the DOC concentration measured in both the blank test and the 2,4-D essays (25 $\mathrm{mg} \mathrm{L}^{-1}$ compared to $17 \mathrm{mg} \mathrm{L}^{-1}$ and $16 \mathrm{mg} \mathrm{L}^{-1}$ ); the final mineralization yield was thus $85 \%$. Chlorohydroquinone, the main degradation by-product (35\% of the residual DOC [37]) was also monitored by HPLC and analysis showed its total removal within the first two days of biological treatment. It can be therefore assumed the presence of refractory degradation products in the oxidized effluent, which could not be assimilated by microorganisms even after 21 days of activated sludge culture. As presented in Table 1, Chemical Oxygen Demand confirmed the removal of degradation by-products, since a decrease from $130 \mathrm{mg} \mathrm{O}_{2} \cdot \mathrm{L}^{-1}$ to 40 $\mathrm{mg} \mathrm{O}_{2} \cdot \mathrm{L}^{-1}$ was measured (corresponding to a $69 \%$ decrease). Even though final COD of 2,4-D samples and oxidized 2,4-D samples were similar, the decrease percentage was lower in case of oxidized 2,4-D samples, as also observed for DOC values.

\section{Conclusions}

A 2,4-D solution was electrochemically pre-treated in order to increase the biodegradability of the solution. After a single pass through the electrochemical flow cell, the solution was collected and subsequently aerobically treated using activated sludge. DOC measurements showed that in the oxidized solution, a high mineralization was observed during the first two days of culture (about 66\%), probably including the mineralization of Chlorohydroquinone. This rapid mineralization step occurred 8 days before the mineralization observed in the 2,4-D samples. Then mineralization only increased to 79 and $85 \%$ after 7 and 21 days, respectively. 
Even though Chlorohydroquinone has been quickly removed, the Dissolved Organic Carbon concentration in the oxidized solution samples at the end of the experiment remained slightly higher than in the blank sample, showing that a small part of the degradation products could not be easily assimilated by the considered sludge. This result could be improved by optimizing the pre-treatment step conditions, such as flow rate or even by recycling the effluent through the cell. At the end of the biological treatment, DOC concentrations in the non-pretreated 2,4-D trials and in the blank test were similar, showing that 2,4-D was fully removed; however, no mineralization was detected before day 7 of the biological treatment of 2,4-D solutions, confirming the relevance of the proposed combined process. Indeed, the electrochemical pretreatment improved significantly the mineralization rate and thus significantly shortened the length of the biological treatment. These positive results should be subsequently confirmed on commercial 2,4-D-containing solutions, and then on real effluents such as bottom farm tanks to fully demonstrate the relevance of this coupled processes.

\section{Nomenclature}

2,4-D: 2,4-Dichlorophenoxyacetic acid

SBRs: Sequencing Batch Reactors

AOPs: Advanced Oxidation Processes

SCE: Saturated Calomel Electrode

HPLC: High Pressure Liquid Chromatography

LC/MS/MS: Liquid Chromatography/Mass Spectroscopy/Mass Spectroscopy

GC/MS: Gas Chromatography/Mass Spectroscopy

DOC: Dissolved Organic Carbon

NPOC: Non Purgeable Organic Carbon

COD: Chemical Oxygen Demand 
$\mathrm{BOD}_{5}$; Biological Oxygen Demand after 5 days

\section{References}

[1] M. Younes, H. Galal-Gorchev, Pesticides in drinking water-A case study, Food and Chemical Toxicology. 38, Supplement 1 (2000) S87-S90.

[2] S. Chiron, A. Fernandez-Alba, A. Rodriguez, E. Garcia-Calvo, Pesticide chemical oxidation: state-of-the-art, Water Research. 34 (2000) 366-377.

[3] R.D. Wilson, J. Geronimo, J.A. Armbruster, 2,4-D dissipation in field soils after applications of 2,4-D dimethylamine salt and 2,4-D 2-ethylhexyl ester, Environmental Toxicology and Chemistry. 16 (2009) 1239-1246.

[4] C. Botrè, F. Botrè, F. Mazzei, E. Podestà, Inhibition-based biosensors for the detection of environmental contaminants: Determination of 2, 4-dichlorophenoxyacetic acid, Environmental Toxicology and Chemistry. 19 (2009) 2876-2881.

[5] M.A. Lemus, T. López, S. Recillas, D.M. Frías, M. Montes, J.J. Delgado, et al., Photocatalytic degradation of 2,4-dichlorophenoxyacetic acid using nanocrystalline cryptomelane composite catalysts, Journal of Molecular Catalysis A: Chemical. 281 (2008) 107-112.

[6] A. Laganà, A. Bacaloni, I. De Leva, A. Faberi, G. Fago, A. Marino, Occurrence and determination of herbicides and their major transformation products in environmental waters, Analytica Chimica Acta. 462 (2002) 187-198.

[7] E. El-Bestawy, H.-J. Albrechtsen, Effect of nutrient amendments and sterilization on mineralization and/or biodegradation of 14C-labeled MCPP by soil bacteria under aerobic conditions, International Biodeterioration \& Biodegradation. 59 (2007) 193-201.

[8] S.S. Mangat, P. Elefsiniotis, Biodegradation of the herbicide 2,4-dichlorophenoxyacetic acid (2,4-D) in sequencing batch reactors, Water Research. 33 (1999) 861-867.

[9] H. Johannesen, J. Aamand, Mineralization of aged atrazine, terbuthylazine, 2,4-D, and mecoprop in soil and aquifer sediment, Environmental Toxicology and Chemistry. 22 (2009) 722-729.

[10] M.E. DeLorenzo, G.I. Scott, P.E. Ross, Toxicity of pesticides to aquatic microorganisms: A review, Environmental Toxicology and Chemistry. 20 (2009) 84-98.

[11] C. Cox, 2,4-D: ecological effects. Herbicide factsheet., J. Pestic. Reform. 19 (3) (1999) 9-14.

[12] W.C. Evans, B.S.W. Smith, H.N. Fernley, J.I. Davies, Bacterial metabolism of 2,4dichlorophenoxyacetate, Biochem J. 122 (1971) 543-551. 
[13] S. Kilpi, V. Backström, M. Korhola, Degradation of 2-methyl-4-chlorophenoxyacetic acid (MCPA), 2,4-dichlorophenoxyacetic acid (2,4-D), benzoic acid and salicylic acid by Pseudomonas sp. HV3, FEMS Microbiology Letters. 8 (2006) 177-182.

[14] J.M. Bollag, G.G. Briggs, J.E. Dawson, M. Alexander, 2,4-D metabolism. Enzymic degradation of chloropyrocatechols, J. Agric. Food Chem. 16 (1968) 829-833.

[15] J.M. Tiedje, J.M. Duxbury, M. Alexander, J.E. Dawson, 2,4-D metabolism: pathway of degradation of chlorocatechols by Arthrobacter sp, J. Agric. Food Chem. 17 (1969) 1021-1026.

[16] P.R. Fisher, J. Appleton, J.M. Pemberton, Isolation and Characterization of the PesticideDegrading Plasmid pJP1 from Alcaligenes Paradoxus., J. Bacteriol. 135 (1978) 798-804.

[17] J.S. Yadav, C.A. Reddy, Mineralization of 2,4-Dichlorophenoxyacetic Acid (2,4-D) and Mixtures of 2,4-D and 2,4,5-Trichlorophenoxyacetic Acid by Phanerochaete chrysosporium, Appl. Environ. Microbiol. 59 (1993) 2904-2908.

[18] K.-H. Oh, O.H. Tuovinen, Degradation of 2,4-dichlorophenoxyacetic acid by mixed cultures of bacteria, Journal of Industrial Microbiology \& Biotechnology. 6 (1990) 275-278.

[19] N.P. Hill, A.E. Mclntyre, R. Perry, J.N. Lester, Behaviour of chlorophenoxy herbicides during the activated sludge treatment of municipal waste water, Water Research. 20 (1986) 45-52.

[20] E. Celis, P. Elefsiniotis, N. Singhal, Biodegradation of agricultural herbicides in sequencing batch reactors under aerobic or anaerobic conditions, Water Research. 42 (2008) 3218-3224.

[21] E. Piera, J.C. Calpe, E. Brillas, X. Domènech, J. Peral, 2,4-Dichlorophenoxyacetic acid degradation by catalyzed ozonation: TiO2/UVA/O3 and Fe(II)/UVA/O3 systems, Applied Catalysis B: Environmental. 27 (2000) 169-177.

[22] P. Drzewicz, M. Trojanowicz, R. Zona, S. Solar, P. Gehringer, Decomposition of 2,4dichlorophenoxyacetic acid by ozonation, ionizing radiation as well as ozonation combined with ionizing radiation, Radiation Physics and Chemistry. 69 (2004) 281-287.

[23] E. Brillas, J.C. Calpe, P.-L. Cabot, Degradation of the herbicide 2,4-dichlorophenoxyacetic acid by ozonation catalyzed with Fe2+ and UVA light, Applied Catalysis B: Environmental. 46 (2003) 381391.

[24] Q. Wang, A.T. Lemley, Kinetic Model and Optimization of 2,4-D Degradation by Anodic Fenton Treatment, Environmental Science \& Technology. 35 (2001) 4509-4514.

[25] E. Brillas, J.C. Calpe, J. Casado, Mineralization of 2,4-D by advanced electrochemical oxidation processes, Water Research. 34 (2000) 2253-2262.

[26] C. Badellino, C.A. Rodrigues, R. Bertazzoli, Oxidation of pesticides by in situ electrogenerated hydrogen peroxide: Study for the degradation of 2,4-dichlorophenoxyacetic acid, Journal of Hazardous Materials. 137 (2006) 856-864. 
[27] X. Quan, S. Chen, J. Su, J. Chen, G. Chen, Synergetic degradation of 2,4-D by integrated photo- and electrochemical catalysis on a Pt doped TiO2/Ti electrode, Separation and Purification Technology. 34 (2004) 73-79.

[28] S.P. Kamble, S.P. Deosarkar, S.B. Sawant, J.A. Moulijn, V.G. Pangarkar, Photocatalytic Degradation of 2,4-Dichlorophenoxyacetic Acid Using Concentrated Solar Radiation: Batch and Continuous Operation, Industrial \& Engineering Chemistry Research. 43 (2004) 8178-8187.

[29] A.D. Modestov, O. Lev, Photocatalytic oxidation of 2,4-dichlorophenoxyacetic acid with titania photocatalyst. Comparison of supported and suspended TiO2, Journal of Photochemistry and Photobiology A: Chemistry. 112 (1998) 261-270.

[30] S. Parra, S. Malato, C. Pulgarin, New integrated photocatalytic-biological flow system using supported TiO2 and fixed bacteria for the mineralization of isoproturon, Applied Catalysis B: Environmental. 36 (2002) 131-144.

[31] M.J. Farré, M.I. Maldonado, W. Gernjak, I. Oller, S. Malato, X. Domènech, et al., Coupled solar photo-Fenton and biological treatment for the degradation of diuron and linuron herbicides at pilot scale, Chemosphere. 72 (2008) 622-629.

[32] H.D. Doan, J. Wu, R. Mitzakov, Combined electrochemical and biological treatment of industrial wastewater using porous electrodes, Journal of Chemical Technology and Biotechnology. 81 (2006) 1398-1408.

[33] S. Ghafari, M. Hasan, M.K. Aroua, Bio-electrochemical removal of nitrate from water and wastewater-A review, Bioresource Technology. 99 (2008) 3965-3974.

[34] D. Belkheiri, F. Fourcade, F. Geneste, D. Floner, H. Aït-Amar, A. Amrane, Feasibility of an electrochemical pre-treatment prior to a biological treatment for tetracycline removal, Separation and Purification Technology. 83 (2011) 151-156.

[35] L. Liu, G. Zhao, Y. Pang, Y. Lei, J. Gao, M. Liu, Integrated Biological and Electrochemical Oxidation Treatment for High Toxicity Pesticide Pollutant, Ind. Eng. Chem. Res. 49 (2010) 5496-5503.

[36] N.A. Salles, F. Fourcade, F. Geneste, D. Floner, A. Amrane, Relevance of an electrochemical process prior to a biological treatment for the removal of an organophosphorous pesticide, phosmet, Journal of Hazardous Materials. 181 (2010) 617-623.

[37] J.-M. Fontmorin, S. Huguet, F. Fourcade, F. Geneste, D. Floner, A. Amrane, Electrochemical oxidation of 2,4-Dichlorophenoxyacetic acid: Analysis of by-products and improvement of the biodegradability, Chemical Engineering Journal. 195-196 (2012) 208-217.

[38] V. Sarria, S. Parra, N. Adler, P. Péringer, N. Benitez, C. Pulgarin, Recent developments in the coupling of photoassisted and aerobic biological processes for the treatment of biorecalcitrant compounds, Catalysis Today. 76 (2002) 301-315. 
[39] C. Pulgarin, M. Invernizzi, S. Parra, V. Sarria, R. Polania, P. Péringer, Strategy for the coupling of photochemical and biological flow reactors useful in mineralization of biorecalcitrant industrial pollutants, Catalysis Today. 54 (1999) 341-352.

Table 1: DOC, COD and biodegradability determination of 2,4-D (100 mg. $\left.\mathrm{L}^{-1}\right)$ and electrolyzed solution (5 times diluted).

\begin{tabular}{|c|c|c|c|}
\hline & $\begin{array}{c}\text { COD before the } \\
\text { biological treatment } \\
\left(\mathrm{mg} . \mathrm{L}^{-1}\right)\end{array}$ & $\begin{array}{c}\mathrm{BOD}_{5} / \mathrm{COD} \text { ratio } \\
\text { before the biological } \\
\text { treatment }[37]\end{array}$ & $\begin{array}{c}\text { COD after the } \\
\text { biological treatment } \\
(21 \text { days })\left(\mathrm{mg.L}^{-1}\right)\end{array}$ \\
\hline 2,4-D solution & $182 \pm 4$ & 0.04 [37] & $38 \pm 3$ \\
\hline $\begin{array}{l}\text { Electrolyzed } \\
\text { solution }\end{array}$ & 130 & $0.25[37]$ & $40 \pm 9$ \\
\hline
\end{tabular}




\section{Captions:}

Figure 1: Chemical structures of 2,4-Dichlorophenoxyacetic acid and Chlorohydroquinone.

Figure 2 : Cyclic voltammetry of 2,4-D solution before (--) andafter electrolysis (-) at pH 3, and that of $\mathrm{Na}_{2} \mathrm{SO}_{4} 0.1 \mathrm{M}$ (dot/dash) .Voltammograms recorded at $100 \mathrm{mV} . \mathrm{s}^{-1}$ in $\mathrm{Na}_{2} \mathrm{SO}_{4}$ on a GC electrode.

Figure 3: Biosorption on activated sludge $\left(0.5 \mathrm{~g} \mathrm{~L}^{-1}\right)$ of 2,4-D (100 $\left.\mathrm{mg} \mathrm{L}^{-1}, \mathrm{Na}_{2} \mathrm{SO}_{4} 0.1 \mathrm{M}\right)$ ( $\boldsymbol{\Delta}$ ) and Chlorohydroquinone in the oxidized 2,4-D solution $(\bullet)$.

Figure 4a: Time-courses of the Dissolved Organic Carbon concentration during activated sludge culture on non-pretreated 2,4-D ( $\mathbf{\Delta})$ and oxidized 2,4-D (•) solutions, as well as during the "blank" test, namely activated sludge culture in the absence of any carbon source $(-)$

Figure 4b: Time-courses of the 2,4-D concentration during activated sludge culture on nonpretreated 2,4-D $(\mathbf{\Delta})$ and oxidized 2,4-D (•) solutions. 
Figures :

Figure 1 :<smiles>O=C(O)COc1ccc(Cl)cc1Cl</smiles><smiles>Oc1ccc(O)c(Cl)c1</smiles>

Figure 2 :

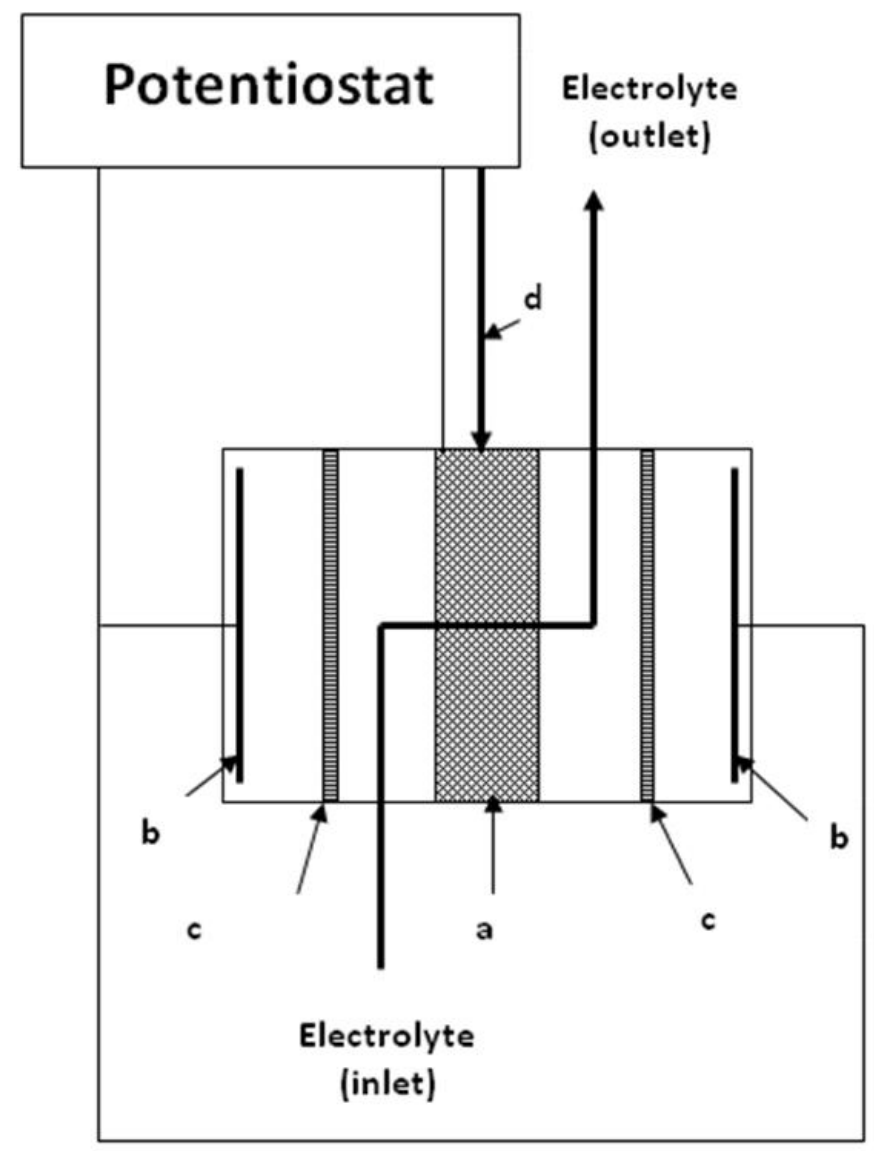

Figure 3 : 


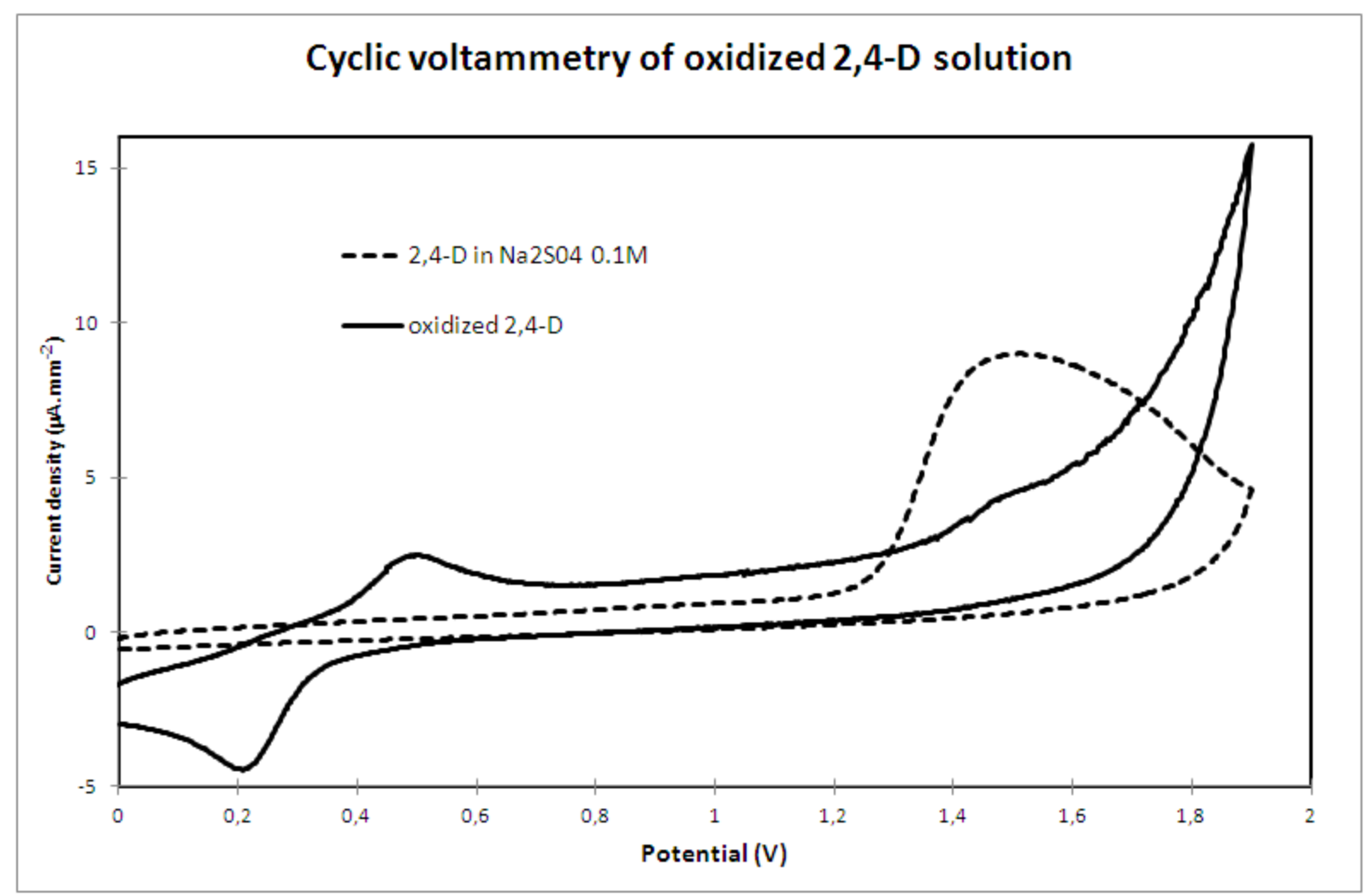

Figure 4 :

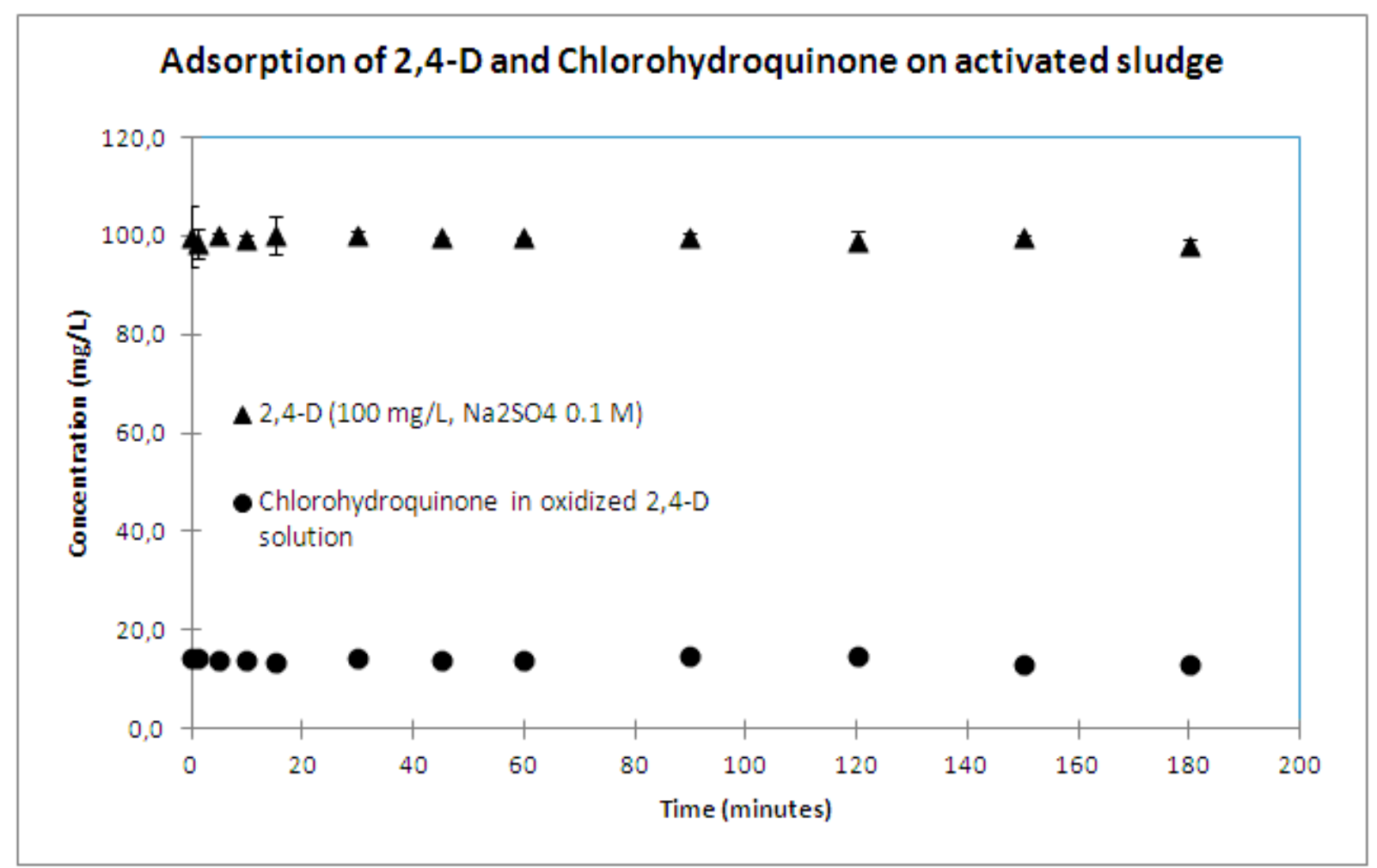


Figure 5a :

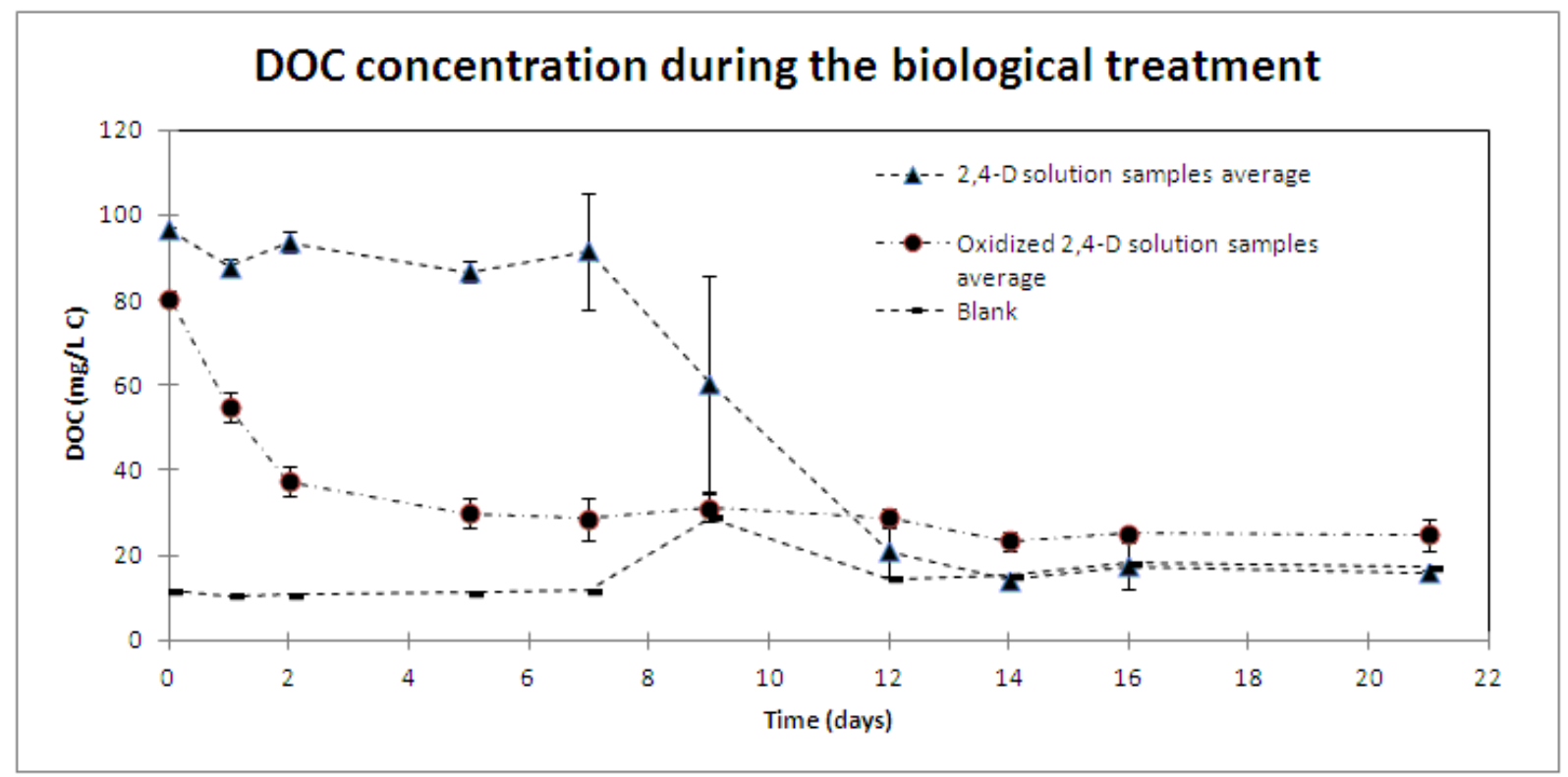

Figure $5 b$ :

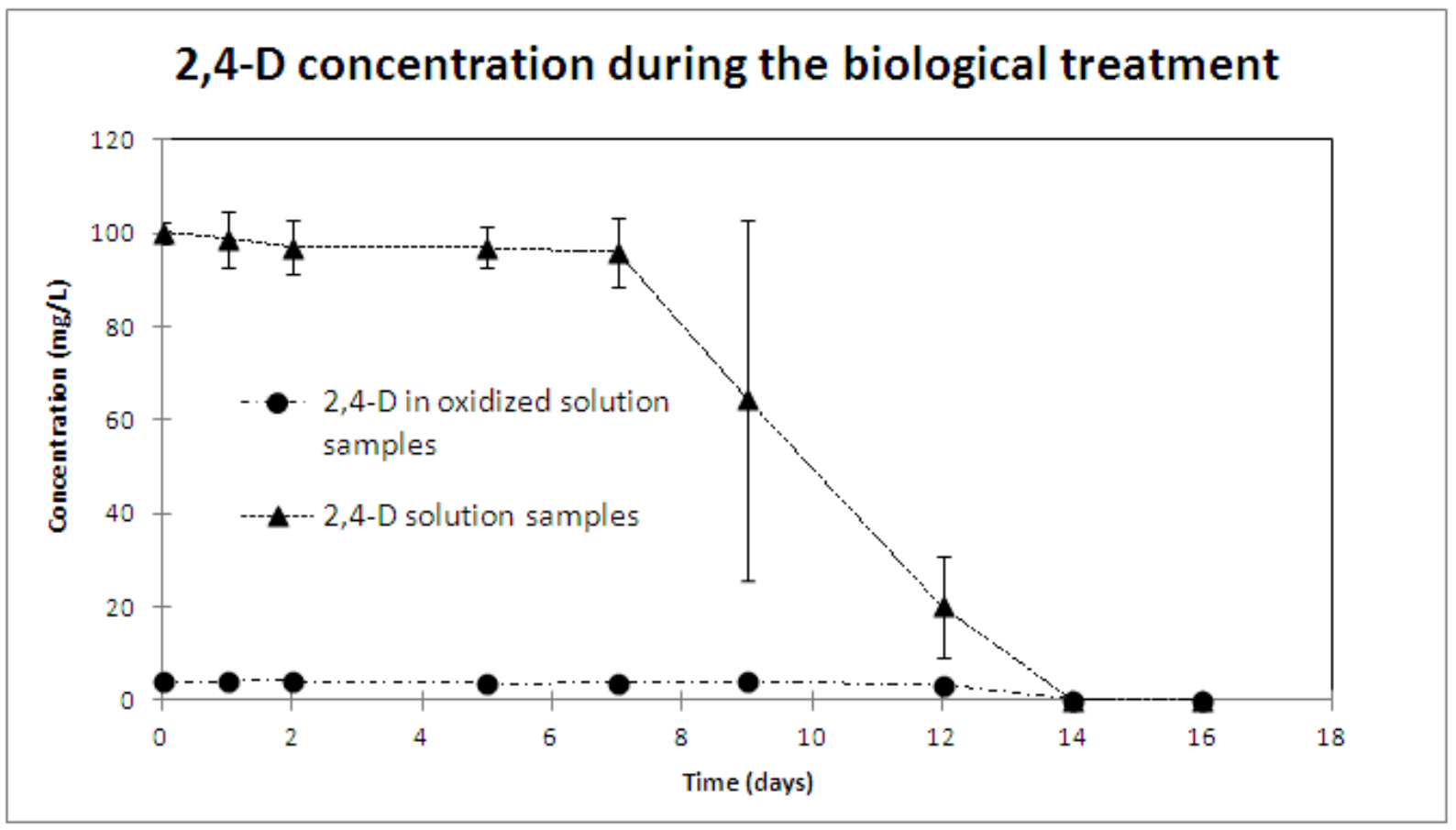

